\title{
Autosomal dominant hyper-IgE syndrome
}

INSERM

\section{Source}

INSERM. (1999). Orphanet: an online rare disease and orphan drug data base. Autosomal dominant hyper-lgE syndrome. ORPHA:2314

Autosomal dominant hyper-IgE syndrome (AD-HIES) is a very rare primary immunodeficiency disorder characterized by the clinical triad of high serum IgE ( $>2000$ $\mathrm{IU} / \mathrm{ml})$, recurring staphylococcal skin abscesses, and recurrent pneumonia with formation of pneumatoceles. 